\title{
Gender Bias: From Classes to Courts ${ }^{\dagger}$
}

\section{Judith Resnik*}

I encountered gender bias early in my teaching career. When I started teaching in large law school classes in the late 1970s, a colleague gave me what he took to be very kind advice. He said:

Be careful. Don't teach in any areas associated with women's issues. Don't teach family law; don't teach sex discrimination. Teach the real stuff, the hard stuff: contracts, torts, procedure, property. And be careful—don't be too visible on women's issues.

At that time, I was working on articles about procedure, habeas corpus, and women in prison. I taught and wrote about all three topics. After a few years, I had to admit that my colleague's remarks were descriptively close to the mark. My virtually all-male colleagues were more interested in my work on procedure and federal courts, and less interested in my work on women in prisons. It was clear that, in those days, being a "player" in the legal academy meant playing in the "big time"-and the big time did not include issues associated with women.

I have told this anecdote before, ${ }^{1}$ and by its telling learned that my experience is neither idiosyncratic nor a tale particular to any law school in the United States. Unfortunately, this description is also not only of historical interest. In 1990, as chair of the Section on Women in Legal Education of the American Association of Law Schools, I repeatedly heard about the risks of being identified with "women's issues." Within the academic community, examples are legion of disinterest as well as hostility to feminist scholarship and commentary.

Thus, the advice ("stay away from 'women's issues" ") is still given. But something has changed. Think about the words: "Be careful; don't teach in any area associated with women's issues." What is the referent for "women's issues"? The assumption is that there is a discrete set of concerns (family

$\dagger$ (C) 1993, Judith Resnik.

* Orrin B. Evans Professor of Law, University of Southern California Law Center. This work has been supported by the University of Southern California Law Center. My thanks to my colleagues on the Task Force, the Honorable John C. Coughenour, Chair, the Honorable Proctor Hug, the Honorable Marilyn Patel, Terry Bird, Margaret McKeown, Henry Shields, and Dr. Deborah Hensler; to Mark Mendenhall of the Circuit Executive's Office; to Chief Judge Clifford Wallace, for his ongoing commitment to these efforts; to all the members of the advisory committees that formed to support this project; to Barbara Babcock, Dennis Curtis, and Vicki Jackson for generous commentary on this work; to editors of the Stanford Law Review, for their engaged editorial work; and to Christine Carr, Angela Johnson, and Veronica Gentilli, whose thoughtful and tireless efforts were critical to the success and joy of the project.

1. Judith Resnik, Visible on "Women's Issues," 77 IowA L. REv. 41, 41 (1991). 
law? sex discrimination?) that are cabined, limited, and walled off from the rest of the stuff of law. The suggestion made is that, if one steers clear of these topics, one is home safe, free from the taint of being labeled a "lightweight" because of one's association with women's issues.

But in the decade plus since I first heard that advice, another lesson has also emerged: There are no safe harbors (if that is what one is seeking) from having to think about the implications of gender. "Women's issues" are a part of all subjects in the law school's curriculum. I am a teacher of procedure and federal courts, as well as of feminism. In my classes, how women and men are treated-as litigants, lawyers, judges, witnesses-is an important aspect of the classroom discussion. Similarly, my colleagues who teach contracts, torts, and property, think about the relationship between those subjects and gender. ${ }^{2}$ Teaching about the federal courts has not insulated me from having to ask about the relationship between law and women and thus has not shielded me from whatever taint comes with being "visible on women's issues."

All of the members of the Ninth Circuit Gender Bias Task Force were appointed because of our expertise in the federal courts-as judges, litigators, or social scientists who do research on federal adjudication. None of us specialize in family or sex discrimination law, but all of us do specialize in thinking about the federal courts. When considering issues of contemporary concern to the federal courts, the topic of gender in general and women in particular emerges. As the Task Force's Preliminary Report ${ }^{3}$ makes plain, all areas of federal law are connected to and affect "women"-and, unfortunately, can provide occasions for gender bias.

One can say with pride that the Ninth Circuit has taken a leadership role in highlighting the connection between federal law and gender. The information provided in the Task Force Report is the result of a truly pioneering study, the first in the federal courts to address gender bias. But amidst the pleasure of beginning this work, we also need to pause to examine the history, and to note with some sadness that the federal courts-until todayhave lagged far behind the states in a willingness to address whether and to what extent invidious biases affect their courtrooms.

A decade ago (at the time when I was being warned off women's issues), the state courts were unabashedly beginning to take up the problem. Begin-

2. See, e.g., Margaret Jane Radin, Market-Inalienability, 100 HARV. L. Rev. 1849 (1987); Carol M. Rose, Women and Property: Gaining and Losing Ground, 78 VA. L. REv. 421 (1992); Marjorie Maguire Shultz, The Gendered Curriculum of Contracts and Careers, 77 IowA L. REv. 55 (1991); Jean Love, Bringing Gender Issues into the Torts Course, Torts and Retorts (Association of American Law Schools, Section on Torts-Compensation Systems), Fall 1989, at 4. See generally Paul M. George \& Susan McGlamery, Women and Legal Scholarship: A Bibliography, 77 Iowa L. REV. 87 (1991) (including references to feminist scholarship throughout the legal curriculum).

3. See Ninth Circuit Task Force on Gender Bias, Executive Summary of the Preliminary Report of the Ninth Circuit Task Force on Gender Bias, 45 STAN. L. REv. 2153 (1993) [hereinafter Ninth Circuit Executive Summary]; The Preliminary Report of THE NinTH Circuit Gender Bias TASK Force: Discussion Draft (1992) [hereinafter Ninth Circuit TASK Force PrelimiNARY REPORT]. 
ning in 1982, state judiciaries began to address gender bias by setting up research committees and task forces. Two years later, New Jersey issued the first report. ${ }^{4}$ By 1988 , the Chief Justices of the state courts had endorsed a resolution, calling for study of racial, ethnic, and gender bias in their courts. ${ }^{5}$ But it was not until August 5, 1992 that, for the first time in the history of the federal judiciary, a circuit judicial conference devoted a day to this issue. That the Ninth Circuit's work is pioneering prompts not only pride but also questions: Why did it take the federal courts so long? How come the state courts took the lead? Is there something in the workplace, jurisdiction, or ideology of the federal courts that led them-us-to sit back and think that the problem of discrimination against women was one "for the state courts?"

One might respond to this question with the comment: Who cares? Who cares that the states came first, and the federal courts second? There is good reason to consider the chronology. One important way in which gender bias operates against women is to make women invisible, to marginalize us, and to assume that what we do is not of great moment or of public significance (just "housekeeping"). ${ }^{6}$ The length of time it took for the federal courts even to ask the "gender" question is thus itself an example of gender bias. And not all the federal courts have yet addressed the issue. As of 1992, the only federal courts to have signed onto the enterprise of examining how gender operates in their courthouses are the Ninth Circuit and the District of Columbia.

Therefore, we have good reason to probe what stands in the way of the federal courts embarking on this project. The answers come in part from the history and the jurisprudence of the federal courts. Looking at the literature about the federal courts, evidence of this form of gender bias-ignoring or marginalizing women-is plentiful. One can read all of the reports, beginning in the 1940s, of the Administrative Office of the United States Courts, ${ }^{7}$ or the speeches on the "state of the judiciary" given by Chief Justices since Warren Burger, ${ }^{8}$ or the more than thirty reports issued in 1992 by federal district courts working in compliance with the Civil Justice Reform Act of $1990^{9}$ - and find hardly a mention of the problems encountered by women as

4. First YeAR REPORT OF THE NEW JERSEY SUPREME COURT TASK ForCE ON WOMEN IN THE COURTS (1984) [hereinafter FIRST YEAR NEW JeRSEY TASK ForCE].

5. Conference of Chief Justices, Resolution XVIII: Task Forces on Gender Bias and Minority Concerns, CT. REV., Fall 1989, at 5.

6. See Judith Resnik, Housekeeping: The Nature and Allocation of Work in Federal Trial Courts, 24 GA. L. REv. 909 (1990).

7. The Director of the Administrative Office of the United States Courts has filed an "Annual Report," describing the "business" of the courts since 1940. See 28 U.S.C. $\$$ 604(a)(3) (1988) (requiring such reports). Each annual report is printed as a section of the Proceedings of the Judicial Conference of the United States.

8. Chief Justice Warren Burger began this practice in 1970. Chief Justice William Rehnquist has continued to provide "Year-End" reports since he assumed the position of chief justice. See, e.g., William H. Rehnquist, Chief Justice's 1991 Year-End Report on the Federal Judiciary, THIRD BraNCH, Jan. 1992, at 1.

9. Pub. L. No. 101-650, 104 Stat. 5089 (codified at 28 U.S.C. $\S \S 471-482$ (Supp. II 1990)). Plans are required by 28 U.S.C. $\$ 472$ (Supp. II 1990). As of the summer of 1992, more than 30 districts have filed "civil justice reform act" plans and reports; women appeared only through the 
litigants, lawyers, and judges. ${ }^{10}$ There is little interest in how the federal courts affect women or are affected by women. ${ }^{11}$

Legal education has also played an important role in making women invisible in the federal courts. It is not only the reports written about and by the federal judiciary that assume the absence of women and women's concerns from the federal judicial agenda. The textbooks, casebooks, and hornbooks of the federal courts also reflect and create this assumption. A review of contemporary books finds little mention of women as a category of litigants. In contrast, in the earliest materials developed in the first part of this century to teach students about the federal courts, the question of whether women had the legal capacity to be litigants in the federal courts occupied teachers and students. ${ }^{12}$ As we women have gained legal recognition as juridical actors within the federal courts, the question of the treatment of women by the federal courts has moved off stage.

Another part of the explanation for the invisibility of women in the federal judiciary comes from data about the employees of the federal courts and about the demographics of those who practice before these courts. As a workplace, the federal courts are a setting in which women-as lawyers and judges-are few in number. As of 1991, 60 of the 94 district courts across the country had no women Article III judges. Four of the thirteen appellate courts had no women appellate judges. As of June, 1992, the United States Supreme Court had appointed special masters more than 80 times: All of those appointed were men. The absence of women from the higher levels of

occasional use of a pronoun. See, e.g., Cost and Delay Reduction Plans for Southern District of Illinois 3 (Dec. 27, 1991) (but using "he" and "his" in discussion of expert witnesses); Cost and Delay Reduction Plans for Southern District of Indiana 10 (Dec. 18, 1991); Cost and Delay Reduction Plans for Southern District of Texas 3 (Oct. 24, 1991); Cost and Delay Reduction Plans for Southern District of California 2 (Oct. 7, 1991).

10. A few of the speeches Chief Justice Burger gave from 1970 to 1985 mention women. See, e.g., Warren E. Burger, Annual Report on the State of the Judiciary, 69 A.B.A. J. 442, 443 (1983) (noting "difficult and complex cases arising out of long overdue recognition of the rights of women and of minorities"); Warren E. Burger, Annual Report to the American Bar Association by the Chief Justice of the United States, 67 A.B.A. J. 290, 290 (1981) (discussing survey finding that " 46 per cent of women and 48 per cent of blacks are 'significantly frightened' by pervasive crime.").

In 1991, Chief Justice Rehnquist made reference to the Violence Against Women Act, which would create a federal civil rights action over claims of violence motivated by gender-based animus. The Chief Justice noted the opposition of the Judicial Conference to the creation of such federal jurisdiction and discussed the importance of reserving the federal courts "for issues where important national interests predominate." Rehnquist, supra note 8, at 2-3.

11. Indeed, a recently published report about the future of the federal courts concluded that "[a]lthough we have confidence that the quality of the federal bench and the nature of federal law keep such problems [of gender bias] to a minimum, it is unlikely that the federal judiciary is totally exempt from instances of this general social problem." FEDERAL CouRTS STUDY CoMmirteE, REPORT OF THE Federal Courts StUdy COMMITTEe 169 (1990).

12. See, e.g., Minor v. Happersett, 88 U.S. (21 Wall.) 162 (1874) (while females were "citizens," the right to vote did not necessarily inhere in the right of citizenship; a Missouri lav' providing only men with the right to vote did not violate the Fourteenth Amendment), discussed in GEORGE W. RIGHTMIRE'S CASES AND READING ON THE JURISDICTION AND PROCEDURE OF THE FEDERAL COURTS 266 (1917). For discussion of the history of this aspect of federal courts' jurisprudence, see Judith Resnik, "Naturally" Without Gender: Women, Jurisdiction, and the Federal Courts, 66 N.Y.U. L. REV. 1682, 1735-50 (1991). 
the workforce could well engender a sense that this workplace did not have much to do with women.

Invisible in the literature of the federal courts. In small numbers in the workplace of the federal courts. And yet a third place in which women are written out of the federal courts is in false assumptions made about the jurisdictional authority of the federal courts. A superficial understanding of the distinctions between state and federal jurisdiction creates an impression that "women's issues"-in the traditional sense-are not much a part of what federal judges have the power to address. Evidence of gender bias can be found in the very description of how litigation is allocated between the state and federal courts and in the assumptions made about the jurisdictional boundaries of the federal courts.

To be sure, there are the obvious examples of cases involving "women's issues" that are acknowledged as occupying an important place on the federal docket: equal protection, reproductive rights, and Title VII litigation. These cases are, however, a small piece of the federal docket, and they cabin women in narrow roles. Aside from discrimination litigation, many people assume that "women's cases" are primarily "family cases"-about issues such as divorce, custody, and how to find protection from violence. A further assumption is that state courts do such "domestic relations" cases and that the federal courts do the "national" work, often described as the public world of commerce, constitutional law, and the federal statutory regime. This assumption about the division of labor between state and federal courts finds expression in the judge-crafted "domestic relations" exception to diversity jurisdiction, which operates at a doctrinal level to express the perceived barrier between the federal courts and "domestic life."13 The twin assumptions-federal courts do not do family law and women's issues are primarily about state-based family law-readily support a conclusion that discrimination against women in the courts is not much a federal problem, but probably a major issue for the states.

But the findings of the Ninth Circuit Task Force belie both these assumptions. First and foremost, women are in the federal docket-as litigants-across a wide spectrum of cases, criminal and civil. The sample of lawyers who practice criminal law reported that 20 percent of the defendants they saw were women. ${ }^{14}$ About half the beneficiaries of federal benefits ${ }^{15}$

13. See Ankenbrandt v. Richards, 112 S. Ct. 2206 (1992) (holding that the domestic relations exception is an interpretation of the reach of the statutory grant of diversity jurisdiction and is limited to excluding cases involving divorce, alimony, and child custody); see also note 22 infra and accompanying text.

The case usually cited as the source of that doctrine is Barber v. Barber, 62 U.S. (21 How.) 582 (1859), which actually held that a federal court in a diversity case could hear a former wife's claim of her husband's failure to pay alimony awarded in a state case. Id. at 591-600. Rogers Smith has described Barber as "the closest the Supreme Court came to enunciating a liberal egalitarian view of the status of women during the antebellum years." Rogers M. Smith, "One United People": SecondClass Female Citizenship and the American Quest for Community, 1 YALE J. L. \& HuMAN. 229, 254 (1989).

14. Ninth Circuit Task Force Preliminary Report, supra note 3, at 144.

15. Id. at 95 . 
and half the immigrants are women. ${ }^{16}$ One study of consumer bankruptcies has found that, in 75 percent of the cases sampled, a woman was the debtor, filing either singly or jointly. ${ }^{17}$ In the Task Force's review of cases involving sexual harassment that resulted in opinions published within this Circuit over a five year period, 92 percent were filed by or on behalf of women. ${ }^{18}$ In short, women are in the federal courts in cases that cut across the federal docket, and women's legal problems are not limited to the problems they encounter in-or attempting to exit-families.

Recall that the other assumption is that the federal courts don't "do" family law. But what the Ninth Circuit Task Force learned is that the federal courts have a lot more to do with "family" law than many want to admit. Since the New Deal, Congress has legislated extensively about family life, and these "federal laws of the family" bring the federal judiciary into a host of problems. However, these laws are not called family law but rather pension, tax, social welfare, and bankruptcy law. For example, in 1984, Congress created federal marital property law by amending the Employment Retirement Income Security Act (ERISA) to provide protection for surviving spouses. ${ }^{19}$ Family life is similarly affected by federal tax and social welfare laws that define households, who heads them, and who are dependents. Bankruptcy law addresses how the filing of bankruptcy affects obligations to pay spouses and children. While federal law forbids discharging debts in bankruptcy for family support, the order of payment among creditors during bankruptcy is not statutorily specified, nor is it always easy to distinguish those debts that are "support" (and not dischargeable) from those that are "property" debts that can be discharged. ${ }^{20}$ Immigration law now provides that the requirement that husband and wife file a joint petition for permanent status can be waived upon a showing of battering or other forms of spousal abuse. ${ }^{21}$ Federal authority over major crimes on Indian reservations within the United States has required federal judges to decide issues related to women as victims of violence.

16. Id. at 105; see also UNITEd STATES IMMigration AND NATURAlization SERviCE, DEPARTMENT OF JUSTICE, 1990 STATISTICAL YEARBOOK OF THE IMMIGRATION AND NATURALIZATION SERVICE.

17. See Teresa A. Sullivan, Elizabeth Warren \& Jay Lawrence Westbrook, As We ForgIve OUR DEBTORS: BANKRUPTCY AND CONSUMER CREDIT IN AMERICA 150 (1989).

18. Ninth Circuit TASK Force Preliminary Report, supra note 3, at 113.

19. ERISA was amended by the Retirement Equity Act of 1984, Pub. L. No. 98-397, 98 Stat. 1426 (codified in scattered sections of 26 U.S.C. and 29 U.S.C.). Ablamis v. Roper, 937 F.2d 1450, 1452 (9th Cir. 1991), is one of the leading cases on the question of the relationship between state family law regimes and federal marital property pension law rights.

20. See, e.g., In re Pacana, 125 B.R. 19 (Bankr. 9th Cir. 1991); Michaela M. White, Spousal and Child Support Payment Provisions in Chapter 13 Plans, 16 CAP. U. L. REV. 369 (1987).

21. In relevant part the regulations state:

A conditional resident who entered into the qualifying marriage in good faith, and who was battered or was the subject of extreme cruelty or whose child was battered by or was the subject of extreme cruelty perpetrated by the United States citizen or permanent resident spouse during the marriage, may request a waiver of the joint filing requirement.

8 C.F.R. \& 216.5 (e)(3) (1992); see Janet M. Calvo, Spouse-Based Immigration Laws: The Legacies of Coverture, 28 SAN DIEGo L. REv. 593 (1991). 
Let me be clear. State law retains enormous power over the status of individuals as married, divorced, parent, and child. But federal legislation of this century has given the federal courts authority over a myriad of economic issues that also structure family life. The world of family law is jointly governed by federal and state law, with varying degrees of jointness depending on the issue. Indeed, the recent Supreme Court decision, Ankenbrandt $v$. Richards, ${ }^{22}$ underscores that the limitations on federal court jurisdiction over "domestic relations" is narrow; federal courts may decline to hear cases under this exception only if those lawsuits are filed under the diversity statute and only if divorce, custody, or alimony are at issue.

To summarize, the Ninth Circuit Gender Bias Task Force asked the "where are the women?" question at several levels: Where are women among the professionals and non-professionals within the courthouse as a workplace? Where are women as litigants? Where are women within the jurisprudence of the federal courts? The Task Force found women materially present (although in small numbers as lawyers and judges) but ideologically absent. Women are everywhere in the federal courts, but no one-until this study-paid much attention. This silence is a form of gender bias, and the work of the Ninth Circuit begins a process of ending that form of discrimination and of understanding the federal adjudicatory world as one that includes women, both out of and as members of families.

We then asked the next question: Does being a woman matter, in terms of process or outcome? Note that while we (like many of the other task forces) use the term "gender bias," rather than terms like "sex discrimination" or "bias against women," much of our focus has, in fact, been on women. These two choices, the deployment of the generic "gender" and the focus on women, need therefore to be explained. During much of the 1970s, scholars and lawyers used the term "sex discrimination" to refer to problems of discrimination encountered by women. In the 1980 s, concerns emerged about how the use of the term "sex" might suggest or justify "natural" distinctions between women and men. Scholars and practitioners turned to the word "gender" to underscore that "gender is not a unitary, or "natural" fact, but takes shape in concrete, historically changing social relationships." ${ }^{23}$ As Joan Wallach Scott has defined the term, gender "means knowledge about sexual difference ... produced by cultures and societies of human relationships . . ." 24 By using the words "gender bias," we are therefore able to attend to the construction of attributes and assumptions about women and men within a gender system and are not lulled into assumptions about some imagined "state of nature."

But deployment of the word "gender" also brings its own concerns; since we all have "gender," one might claim that the problems encountered by

22. 112 S. Ct. 2206 (1992); see also note 13 supra.

23. Barrie Thorne, Cheris Kramarae \& Nancy Henley, Introduction to LANGUAGE, GENDER, AND SOCIETY: OPENING A SECOND DECADE OF RESEARCH IN LANGUAGE GENDER AND SOCIETY 7, 16 (Barrie Thorne, Cheris Kramarae \& Nancy Henley eds., 1983).

24. Joan Wallach Scott, Gender and the Politics of History 2 (1988). 
women and men are equivalent, and that the ongoing struggle for women's equality might become blurred by the choice of language. ${ }^{25}$ Therefore, the decision to use the concept of gender to underscore the unnaturalness of the inequalities between women and men must be balanced by a second choice, to focus on the harms that the current gender system does to women. ${ }^{26}$ Here again, the Ninth Circuit Task Force's concern about women is shared with other gender bias task forces; we, like them, are thus subjected to the question of whether the focus on women reflects our own bias, against men.

As is explained in the Preliminary Report, we did not at the outset impose any one definition of bias; indeed, we did not look for bias, per se, but rather for the effects, if any, of gender. ${ }^{27}$ Our findings comport with those of other gender bias task forces; women reported the bulk of the gender-based problems. While men on rare occasions described being the victims of gender bias, women disproportionately felt the injuries of gender. Thus, the discussion centers on the difficulties encountered by women, but, as the report indicates, we did find a few instances (such as sentencing) in which gender may work to women's advantage-or more accurately, to the advantage of white women in certain roles.

The effects of gender in sentencing illuminate two other important aspects of discussions of gender bias: that discrimination against men takes forms different from that against women, and that "men" and "women" may themselves be too general terms. The concern that women are treated "better" by prosecutors in bargaining over charges or sentences is the subject of this Circuit's Redondo-Lemos opinion. ${ }^{28}$ As that case details, the claim of gender bias harming men is based on the assumption that men are more important actors (in this context, more likely to be culpable criminally) than are women, who when involved in crimes are assumed to occupy traditional women's roles. The cultural bias that perceives women as marginal and less important actors is here turned into women's advantage. Trivialization of

25. See generally Christine A. Littleton, Does It Still Make Sense to Talk about "Women"?, 1 UCLA WOMEN'S L.J. 15 (1991).

26. The titles of 24 published reports reflect both the deployment of the term "gender" and the focus on women. Seven use the word "women" in the title of the report. See, eg., Lousiana TASK Force ON WOMEN IN THE COURTS, FINAL REPORT (Louisiana, 1992); FINAL REPORT OF THE New Mexico State Bar Task Force on Women and the Legal Profession (New Mexico, 1990); FIRST YEAR NEW JERSEY TASK ForCE, supra note 4. Fourteen reports use "gender." See, e.g., REPORT OF THE CONNECTICUT TASK FORCE, GENDER, JUSTICE AND THE COURTS (Connecticut, 1991); Colorado SUPREME COURT TASK ForCE ON GENDER BIAS IN THE COURTS, GENDER \& JUSTICE IN THE COLORADo CouRTS (Colorado, 1990) [hereinafter Colorado TASK ForCE]; Final REPORT OF THE Michigan SUPREME COURT TASK Force ON GENDER ISSUES IN THE CourTs (Michigan, 1989). Two used "gender" and referred to "women and men" in their titles. See Kentucy Task Force on Gender Fairness and the Courts, EQUal Justice for WoMEN AND MEN (Kentucky, 1992); ACHIEVING EQUAL JUSTICE FOR WOMEN AND MEN IN THE COURTS, DRAFT REPORT OF THE JUDICIAL COUNCIL ADVISORY COMMTTTEE ON GENDER BIAS IN THE COURTS (California, 1990). One used "equal justice" and made no reference to either women or men or gender. See Wisconsin EQUAL JUSTICE TASK ForCE: Final REPORT (Wisconsin, 1991).

27. Ninth Circuit Executive Summary, supra note 3, at 2154-55.

28. United States v. Redondo-Lemos, 955 F.2d 1296 (9th Cir.), as amended on denial of reh'g, 1992 U.S. App. LEXIS 10071 (1992) (en banc). 
the role of women works to harm men because, in the criminal context, being viewed as a minor figure is the desired goal.

But experts on sentencing data also informed us that the assumption of women's marginality may intersect with other biases. Although some women may have advantages in charge bargaining, those advantages may not be available equally to all women. Claimed "advantages" of women may be advantages that inure to white women, or women in certain kinds of criminal activity, or women in certain social settings. Thus, the words "women" and "men" may at times be inadequate to capture the intersections of gender, race, religion, ethnicity, sexual orientation, and class.

Further, that women and men have different socially-ascribed roles may also require that responses to gender bias take those differences into account. Data on state prisoners report that nearly 80 percent of mothers as compared to 50 percent of fathers lived with minor children before entering prison. Ninety percent of males reported that their wives were caring for their children during the time when they, the fathers, were incarcerated, while 22 percent of the women reported that their husbands were caring for their children when they, the mothers, were in prison. ${ }^{29}$ In quick translation, the data tell us what we know: Women are more often the caregiving parents than are men.

In the federal system, contemporary sentencing law struggles with these differences in women's and men's provision of child care. The United States Sentencing Commission has determined that "family ties and responsibilities ... are not ordinarily relevant in determining whether a sentence should be outside the applicable guideline range." 30 Judges across the country find the application of this rule troubling, as is illustrated by a series of opinions discussing the sentencing of women who are primary caretakers of children. ${ }^{31}$ Further, data on women and men in federal prisons illustrate other

29. See U.S. Department of Justice, LaWrence A. Greenfeld \& Stephanie MinorHarper, Women in PRISON 6-7 (1991).

30. See United States Sentencing Commission, Federal Sentencing Guidelines MANUAL § 5H1.6 (policy statement) (1993 ed.) issued in response to 28 U.S.C. § 994(e) (1988), which provides that guidelines and policies on sentencing should "reflect the general inappropriateness of considering the education, vocational skills, employment record, family ties and responsibilities and community ties of the defendants."

31. Several courts have held that the effect that sentencing a single parent to prison has on a young child is not an "extraordinary" circumstance justifying a downward departure. See, e.g., United States v. Chestna, 962 F.2d 103, 107 (1st Cir.), cert. denied, 113 S. Ct. 334 (1992); United States v. Headley, 923 F.2d 1079, 1082 (3d Cir. 1991); United States v. Brand, 907 F.2d 31, 33 (4th Cir.), cert. denied, 498 U.S. 1014 (1990); United States v. Brewer, 899 F.2d 503, 506-08 (6th Cir.), cert. denied, 498 U.S. 544 (1990); .

In contrast, the Second Circuit concluded that a single mother responsible for raising four young children classified as extraordinary family circumstances that justified a substantial downward departure. United States v. Johnson, 964 F.2d 124, 127-30 (2d Cir. 1991); see also United States v. Pena, 930 F.2d 1486, 1494-95 (10th Cir. 1992) (upholding a downward departure based in part on the fact that a woman was the sole support of two young children).

A number of federal district courts have also granted departures to single mothers, in part on the basis of responsibility to family. See, eg., United States v. Gerard, 782 F. Supp. 913, 914-15 (S.D.N.Y. 1992) (sole provider for two teenage children); United States v. Pokuaa, 782 F. Supp. 747 (E.D.N.Y. 1992) (risk of loss of child custody); United States v. Floyd, 738 F. Supp. 1256, 1261 (D. 
differing impacts of incarceration. Women, who are a growing proportion of incarcerated prisoners, are often incarcerated at great distances from their homes-farther away in general than are men, for whom there are more federal facilities. Not surprisingly, one study by the United States Bureau of Prisons of four federal facilities also found that the children of male inmates lived closer to the institutions at which a parent was incarcerated than did the children of female inmates. ${ }^{32}$

Thus the richness and complexity of the topic of gender bias is revealed: that bias based on gender operates differently against women and men and varies with sexual orientation, race, ethnicity, religion, and class; that given the differing histories and social roles of women and men, the same treatment of women and men may, when considered in context, constitute gender bias toward women; and that all women and all men cannot be equated because of the importance of race, ethnicity, sexual orientation, and class. The Ninth Circuit Task Force has attempted to address some of this complexity, as we explored the impact of gender in immigration, criminal justice, federal benefits, and federal Indian law. However, we must note that there is much more to know and that current data wrongly cabin our knowledge and understanding. For example, much of the available demographic information relies on drawing distinctions between women and men, on the one hand, and among "minorities" on the other-thus making invisible the woman who is also a member of an ethnic or racial minority.

Therefore, the Task Force often asked, at the more general level, about the experiences of women and men in the aggregate. We inquired: Does it matter if one is a woman or a man when one is a litigant? This is a critical question, to ensure that task forces do not look only to the internal workings of court systems but also focus on a central purpose of court systems: responding to citizens' disputes. Given the many variables that affect adjudication, this central question is also the most difficult to answer. It is a lot easier to report the number of women who hold a certain position than to determine how gender affects the process and outcome of cases. To explore preliminarily these issues of gender and adjudication, the Task Force relied on Advisory Committees, comprised of individuals expert in particular areas of law, who generously volunteered their time and undertook special studies. $^{33}$

Minn. 1990) (single mother with four children between the ages of three months and nine years); see also United States v. Big Crow, 898 F.2d 1326, 1331-32 (8th Cir. 1990) (downward departure for a man who supported his family).

32. Ninth Circuir Task Force Preliminary Report, supra note 3, at 160 (citing OfFice of Research and Evaluation Bureau of Prisons, Steven McPeek \& Shau-Fai TSe, Final Report: Bureau of Prisons Parenting Programs: Use, Costs, and Benefits 1 (1988)).

33. Six Advisory Committees were formed: the Advisory Committee on Federal Indian Law, convened by Professor Barbara Atwood of the University of Arizona College of Law; the Advisory Committee on Employment Law, convened by Carol Sobel of the American Civil Liberties Union of Southern California; the Advisory Committee on Bankruptcy, convened by the Honorable Lisa Hill Fenning, Bankruptcy Judge of the Central District of California; the Advisory Committee on Immigration, convened by Professors Evangeline Abriel of Loyola-New Orleans Law School, Carolyn Patty Blum of Boalt Hall, Abby J. Liebman of the California Women's Center, Lynn Alvarez of the 
Credibility of women as witnesses emerged as a serious concern from inquiries in several areas, including federal benefits, immigration, and employment law. Many reported that women litigants are assumed to be less credible or their problems less important than those of men. The Task Force learned that women's testimony may simply be thought to be complaints about life, rather than as legally cognizable harms, and that, even when believed, women's injuries may be trivialized or viewed as not "worth much" in monetary terms. These descriptions parallel those from state gender bias task forces, which have addressed the treatment of women as witnesses in other areas, such as domestic violence, but which have also reached similar conclusions: Women are often disbelieved because they are women. ${ }^{34}$

Moreover, even when believed, women's claims may be ignored or devalued. Lawyers in federal employment cases reported their experiences before district and magistrate judges who were not interested in these cases, described as "small value" claims. In contrast, at the appellate level, the Ninth Circuit has taken a leadership role in defining women's rights to be free from unwanted sexual harassment: Ellison v. Brady's "reasonable woman" approach is based on the experiences of women. ${ }^{35}$ The Advisory Committee on Employment Law looked at the 26 reported Ninth Circuit appellate cases over the past five years involving sexual harassment; in 23 of the 26 cases, defendants had prevailed at the trial level. In 52 percent of those trial court wins, on appeal the decisions were reversed in part or in full on procedural or substantive grounds. That reversal rate of 52 percent is much higher than the 15 to 20 percent reversal rate for all private civil cases during the same time period. Thus, the interplay described by the lawyers in this area-of trial court disinterest as contrasted with appellate court leadership in under-

Immigration Rights Office, Legal Aid Foundation of Los Angeles, Myrna Raeder of Southwestern Law School and Elizabeth Atlee of the University of Southern California; the Advisory Committee on Federal Benefits Law, convened by Professor Joan Schaffner of George Washington Law School; the Advisory Committee on Criminal Justice Issues, convened by Denise Meyer and Maria Valdez of the Federal Public Defenders Office of Los Angeles, Professor Myrna Raeder, Maria E. Stratton and Melissa N. Widdifield of Talcott, Lightfoot, Vandevelde, Woehrle \& Sadowsky, and Lee Seltman and Heidi Binford of the University of Southern California.

34. Almost all of the published gender bias task force reports address questions of credibility, as parts of discussions of domestic violence, sexual assault, courtroom interaction, and rights sought by women litigants under employment and federal benefits law. Many of the reports detail the specific problems faced by women testifying about sexual aggression. Illustrative is the finding of the District of Columbia that "cross-examination of victims tends to be more hostile in sexual assault cases than in other assault cases." THE FINAL REPORT OF THE TASK FORCE ON RACIAL AND ETHNIC BIAS AND TASK Force ON GENDER BIAS IN THE COURTS 119 (District of Columbia, 1992); see also Colorado TASK FORCE, supra note 26, at 92; GENDER AND JUSTICE IN THE COURTS: A REPORT TO THE SUPREME COURT OF GEORGIA BY THE COMMISSION ON GENDER BIAS IN THE JUdICIAL SYSTEM 93-94 (1991); THE 1990 REPORT OF THE ILLINOIS TASK FORCE ON GENDER BIAS IN THE COURTS 106 (1990); Report OF THE Gender Bias Study OF THE SUPREME JUdicial CourT 107-108 (Massachusetts, 1989).

When discussing "domestic" violence, several reports describe how victims are blamed, are accused of provoking attacks, are treated as though their experiences are trivial, and are disbelieved. See, e.g., Report of the SPEcial Joint Committee on Gender Bias IN the COURTS 3.5 (Maryland, 1989); MinNesota SuPREME COURT TASK ForCE FOR GENDER FAIRNESS IN THE COURTS, reprinted in 15 WM. MrTCheLl L. REV. 825, 875-77 (1989).

35. 924 F.2d 872, 878-80 (9th Cir. 1991). 
standing the rights of women - can be found in the case law as well as in the experiences of members of this segment of the bar.

Although the work on substantive areas of law is preliminary in nature, much of it is remarkably consistent. Our data came from many sources and in many forms. Across subject matters and districts, we heard overlapping and corroborating reports. We heard that gender counts, that in adjudication, whether you are a woman or a man affects the courtroom, the chambers conference, the perception of your credibility, the amount of damages you may receive, or the view of the importance of your claim.

But, as our data detail, we also learned that, if you are a male lawyer or male judge, you are less likely to perceive gender as having any relevance. We heard reports from men, lawyers and judges, that there is "no gender bias" or precious little of it. ${ }^{36}$ In contrast, almost all women-be they administrative law judges, trial judges or appellate judges, trial lawyers, partners at large firms or in small practices, old or young-reported "some" to "frequent" instances of gender bias. We were particularly conscious of one aspect of the data, that neither age nor professional role explains differences in perceptions of the existence and frequency of gender bias. Whether older or younger members of the bar or bench, men saw the world one way, women another.

What explains these differences in perceptions? One lawyer (in the hundreds of handwritten "margin" comments that we received) offered an explanation: "One of us, either you or I, is living in Disneyland." 37 The Task Force offers other interpretations, less fantastical. First, women and men do not always have the same experiences. A few years ago, I stood up in a court, about to make a formal motion, and was greeted with a judge asking what I, "a lady lawyer," wanted. ${ }^{38}$ I was then asked by the marshal how I could be cute and yet efficient. The court clerk said to me later: "Come back, we make home movies on the weekends." Obviously, male lawyers have not often been the recipients of such comments, but almost every woman lawyer and judge can tell a variant of this very story.

So, of course, women and men have different experiences in the courtroom, on and off the record. But women and men may also have the same experiences, hear the same words, see the same events, yet understand them differently. If I sit in a room as one of 16 women in a room of 100 men (which is the ratio of women to men in the bar of the Ninth Circuit), I may well experience that meeting as a place with very few women, and maybe feel a bit daunted. I might wonder how welcome I am, think about what if any-

36. As one male lawyer put it: "I have never witnessed nor heard of a single incident of gender bias." Christine Carr, Compilation and Analysis of the Margin Comment Responses to the Ninth Circuit Gender Bias Task Force's Surveys, Working Paper prepared for the Ninth Circuit Gender Bias Task Force (June, 1992) (unpublished manuscript, on file with the author) [hereinafter Margin Comments].

37. Ninth Circuit Task Force Preliminary Reporr, supra note 3, at 172.

38. Although separated in time by some 75 years, Clara Foltz and I were both addressed as the "lady lawyer." See Barbara Allen Babcock, Western Women Lawyers, 45 STAN. L. REv. 2179, 2184 (1993). 
thing to say, and, if I speak, be aware of myself as disproportionately visible. Women lawyers and judges told us repeatedly about their sense of isolation and of being out of place and their struggle to feel comfortable. As one woman put it, the federal courts remain "a bastion of male lawyers." Another described the conflict-between appearing "ladylike" and passive, and receiving complaints from men about being insufficiently aggressive, or appearing forceful and aggressive, and then being subjected to accusations of being "emotional," "strident," or "argumentative." She continued: Gender bias "places an additional burden on women lawyers who are constantly having to engage in a balancing act just to do" their job. ${ }^{39}$

Many male white lawyers may sit in rooms full of colleagues and have a sense of comfort, of place, and of belonging to the club. They may be oblivious to gender or may, if they notice and reflect on the presence of women at all, think that there are a fair number of women. Women's sense of being out of place is reinforced by interactions among colleagues and opponents in the informal settings of pretrial conferences, in the administrative adjudicatory arena that generates records for the appellate and trial courts to review, and sometimes in the very rules of law.

Participating in the Task Force provided another window into the experiences of derogation and trivialization that women sometimes face. As detailed by Dr. Hensler, ${ }^{40}$ the Task Force received an unusually large number of hand-written margin comments, for which we are very grateful. While many offered support, amplification, and assistance, some of those comments were pretty angry: ranging from telling us that this activity was stupid and wasteful ("a complete waste of time and money!"; "a pile of garbage"; "much ado about nothing") to telling us that we were doing something harmful by asking questions about gender. One comment, by a male lawyer, summed up many: "Why the Ninth Circuit should focus on gender bias is beyond me when there are real legitimate problems within the Ninth Circuit which are not being addressed."41

We on the Task Force have compared notes with members of other special committees of the Ninth Circuit-who worked on projects such as sanctions against lawyers and judges imposed under Rule 11 of the Federal Rules of Civil Procedure and the role of magistrate judges. Those groups did not receive comments of a similar tenor; obviously, the world of gender is different. Whatever passions we feel about Rule 11 (and they run high), those feelings are somewhere away from ourselves, and not quite so close to home as what we feel when the topic is gender. On a daily basis, inquiries about gender strike home, as tied up with our identities and the way we view the world. At times, both women and men share the feeling that these questions are close-indeed, too close-for comfort. That proximity translates, some-

39. Margin Comments, supra note 36.

40. Deborah R. Hensler, Studying Gender Bias in the Courts: Stories and Statistics, 45 STAN. L. REv. 2187, 2193 (1993).

41. Margin Comments, supra note 36; see also NinTH Circuir Task Force PReliminary REPORT, supra note 3, at 179. 
times into a reticence, sometimes into a nervousness, laughter and jokes, and sometimes into hostility.

Thus, the work of this and other Task Forces is truly challenging. How can we talk about gender issues? How can we bridge experiences that are so disparate? The perceptions that differ so radically? Can we talk to each other openly and admit the pain, isolation, and injury that many women reported to us-and still adhere to commitments to equal justice? And still see women as powerful lawyers and judges even as these women admit their sense of isolation and the perceptions of vulnerability in a workplace so dominated by men? Let me underscore this point: Being powerful is an essential element of being an effective lawyer or judge. Women who admit the fragility of their position within the federal courts are at risk of reminding their colleagues that we, women, fear disparate treatment. Women lawyers are in an especially precarious position, for we are not only personally vulnerable, our clients are vulnerable as well.

The Task Force heard these concerns repeatedly. One woman lawyer wrote on the questionnaire: 'I've been addressed as 'hon' by a senior judge in this district. I was mildly offended but, because he was a judge and my client was at his mercy, [I was] helpless to respond."42 Another reported that she had complied with a magistrate judge who requested that she leave the room so that he could tell "a dirty joke during a settlement conference." She feared she would jeopardize her clients' interests if she refused. ${ }^{43}$ These concerns about complaining are well-founded; one runs the risk of appearing inappropriately sensitive or insufficiently powerful. As one male lawyer wrote: "There are a small number of female attorneys ... who seem to infer gender bias from almost any situation. These attorneys can be very unpleasant to be around and, in my opinion, hurt their clients' cause." 44 Another stated that "only big boys and big girls are in federal courts, [and] we should be able to take care of ourselves." 45

We on the Task Force understand the instincts to appear invulnerable to insult, as well as the desire to bury or to ignore the differences, and to forge on in the hopes that gender distinctions will just dissipate over time. We wish we could be confident that such an approach would suffice, but unfortunately our data provide no such solace. Serious problems, of communication, process, and outcome need to be addressed. How does one change attitudes, ideology, workplaces? In some sense, courts-both state and federal-face these problems everyday when they have to craft remedies to address legal wrongs. That is the next step, but this work cannot be delegated to a Task Force or to any small set of people. The work of responding to gender bias is work that must proceed not only at this conference, and then at the district-by-district level, but also over time, by succeeding generations.

42. Margin Comments, supra note 36.

43. Ninth Circuit TASK Force Preliminary Report, supra note 3, at 60.

44. Id. at 55.

45. Margin Comments, supra note 36. 
While the Task Force's Preliminary Report offered a series of conclusions about what we have found, at this stage, we deliberately declined to set forth our own recommendations. We believe that we must develop responses and solutions collectively. As this remedial work proceeds, we are concerned that the problem of segregation with which I began remains relevant. For many, "women's issues" continue to be perceived as a discrete set of narrowly-focused problems, cabined off from the full panoply of issues that confront the federal courts, and so, if thought about at all, considered in one context and then ignored. While we rejoice in the dedication of a day of the 1992 Ninth Circuit Judicial Conference to gender bias, we are concerned that participants not walk away with the view that one has done "it," and can now move on. But when considering the other topics of the federal courts agenda, such as the two in this Conference's other programs-long range planning and civility-one needs to ask about gender as well. One long range goal should be to integrate the federal courts as a workplace in which all can feel a part. And as one thinks about civility, one should remember the comment of one woman lawyer: "[U]ncivil behavior occurs with uncivil attorneys, and uncivil attorneys are more uncivil to members of the opposite sex."46 All three topics-long range planning, gender bias, and civility-share a common goal: the search to reframe the administration of justice to conduct the business of the Ninth Circuit in a manner that welcomes all citizens and lawyers as participants, to enable the courts to hear what both men and women have to say, and to create an atmosphere in which there is permission to speak-even about painful issues of courts as places of discrimination.

46. The interrelatedness of the issue of civility and the problems of bias based on gender, race, or ethnicity have not been addressed by some engaged in the "civility" debate. See, e.g., Interim Report of the Committee on Civility of the Seventh Federal Judicial Circuit, 143 F.R.D. 371 (1991); Final Report of the Committee on Civility of the Seventh Federal Judicial Circuit, 143 F.R.D. at 441 (1991) (neither address the effects of gender, race, or ethnicity). 
HeinOnline -- 45 Stan. L. Rev. 2210 1992-1993 